\title{
Viruses in reptiles
}

\author{
Ellen Ariel
}

\begin{abstract}
The etiology of reptilian viral diseases can be attributed to a wide range of viruses occurring across different genera and families. Thirty to forty years ago, studies of viruses in reptiles focused mainly on the zoonotic potential of arboviruses in reptiles and much effort went into surveys and challenge trials of a range of reptiles with eastern and western equine encephalitis as well as Japanese encephalitis viruses. In the past decade, outbreaks of infection with West Nile virus in human populations and in farmed alligators in the USA has seen the research emphasis placed on the issue of reptiles, particularly crocodiles and alligators, being susceptible to, and reservoirs for, this serious zoonotic disease. Although there are many recognised reptilian viruses, the evidence for those being primary pathogens is relatively limited. Transmission studies establishing pathogenicity and cofactors are likewise scarce, possibly due to the relatively low commercial importance of reptiles, difficulties with the availability of animals and permits for statistically sound experiments, difficulties with housing of reptiles in an experimental setting or the inability to propagate some viruses in cell culture to sufficient titres for transmission studies. Viruses as causes of direct loss of threatened species, such as the chelonid fibropapilloma associated herpesvirus and ranaviruses in farmed and wild tortoises and turtles, have re-focused attention back to the characterisation of the viruses as well as diagnosis and pathogenesis in the host itself.
\end{abstract}

\section{Table of contents}

1. Introduction

2. Methods for working with reptilian viruses

3. Reptilian viruses described by virus families

3.1. Herpesviridae

3.2. Iridoviridae

3.2.1 Ranavirus

3.2.2 Erythrocytic virus

3.2.3 Iridovirus

3.3. Poxviridae

3.4. Adenoviridae

3.5. Papillomaviridae

3.6. Parvoviridae

3.7. Reoviridae

3.8. Retroviridae and inclusion body disease of Boid snakes

3.9. Arboviruses

3.9.1. Flaviviridae

3.9.2. Togaviridae

3.10. Caliciviridae

3.11. Picornaviridae

Correspondence: Ellen.Ariel@JCU.edu.au

Microbiology and Immunology, School of Veterinary and Biomedical

Sciences, James Cook University, Townsville, Queensland 4810, Australia

\subsection{Paramyxoviridae}

4. Summary

5. Acknowledgements

6. Competing interests

7. References

\section{Introduction}

The etiology of reptilian viral diseases can be attributed to a wide range of viruses occurring across different genera and families. Thirty to forty years ago, studies of viruses in reptiles focused mainly on the zoonotic potential of arboviruses in reptiles and much effort went into surveys and challenge trials of a range of reptiles with eastern and western equine encephalitis as well as Japanese encephalitis viruses [1-3]. In the past decade, outbreaks of infection with West Nile virus in human populations and in farmed alligators in the USA have seen the research emphasis placed on the issue of reptiles, particularly crocodiles and alligators, being susceptible to, and reservoirs for, this serious zoonotic disease [4-7]. Although there are many recognised reptilian viruses, the evidence for those being primary pathogens is relatively limited. Transmission studies establishing pathogenicity and cofactors are likewise scarce, possibly due to the relatively low commercial 
importance of reptiles, difficulties with the availability of animals and permits for statistically sound experiments, difficulties with housing of reptiles in an experimental setting or the inability to propagate some viruses in cell culture to sufficient titres for transmission studies. Viruses as causes of direct loss of threatened species, such as the chelonid fibropapilloma associated herpesvirus and ranaviruses in farmed and wild tortoises and turtles, have refocused attention back on the characterisation of the viruses $[8,9]$ as well as diagnosis and pathogenesis in the host itself [10-13].

\section{Methods for working with reptilian viruses}

Generally, diagnosis of reptilian viruses can be approached like all other viruses. Histopathology can give the initial indication of a viral infection and most infections are described alongside the pathological changes they induce. Some viruses have been isolated, characterized and used in challenge trials or to produce specific antisera for immunological tests, but like all other fields of virology, reptilian virus researchers are venturing into both serological surveys and molecular tools for diagnosing viral infections [8,14-20].

Isolation of viruses in culture has the advantage of amplifying the agent for easier identification and characterisation, but also for use in transmission studies. Specific reptilian cell lines are available that will support viral growth and for some viruses display cytopathic effect, where others do not cause CPE or do not grow at all in known cell culture systems. For those cell lines that support propagation of a particular virus, the temperature regime for both cell lines and viral growth will be different from mammalian systems due to the poikilothermic nature of reptiles. Zoonotic viruses have been isolated from reptiles since 1939 when Rosenbusch isolated Western Equine Encephalitis from a Bothrops alternate, followed by Japanese encephalitis virus from snakes, calicivirus from snakes, a flavivirus-like agent from tortoises and West Nile virus from alligators using either mammalian derived cell lines at $37^{\circ} \mathrm{C}$ or mosquito cell lines at $28^{\circ} \mathrm{C}$ [7,21-25]. Several other reptilian viruses will grow in cell lines derived from mammals such as Vero cells or in cell lines derived from fish [26,27]. Clark and Karzon isolated a herpesvirus from iguana in tissue explants from an apparently healthy iguana in 1972 [28] and since then several reptilian cell culture systems have been established and are now available from the American Type Culture Collection. Paramyxovirus grows readily in cobra eggs, viper heart, gecko embryo and rattlesnake fibroma cell lines $[29,30]$ and ranavirus will grow in a variety of cell lines including fish cell lines at a range of temperatures below $30^{\circ} \mathrm{C}$ [27].

Where electron microscopy (EM) used to be the ultimate diagnostic tool for viruses, polymerase chain reaction
(PCR) has revolutionized our ability to identify infectious agents with generic and specific primers used for diagnosis. Subsequent sequencing of the viral genome opens possibilities for fast characterization, insight into their phylogenetic relationship and epidemiological investigations. The drastic decrease in the cost of sequencing has turned the diagnostic attention to molecular methods, which has the added advantage of accurate diagnosis and the subsequent possibility of reproducing the antigenic part of the virus, irrespective of our ability to culture the viral pathogen in vitro. However electron microscopy still has a diagnostic role since agents identified under the EM scope may direct the diagnostician toward selecting the best primers to use.

With the current trend and affordable sequencing costs, researchers will keep looking for and finding viruses in reptiles at a great rate and over the next decade we are likely to see the clades being populated with new findings, known isolates being placed into taxonomic relationships and possibly revealing genetic virulence markers.

\section{Reptilian viruses described by virus families}

The type of genome and the presence of an envelope are important in the replication strategy of viruses and subsequently the possibilities of diagnosis, prevention and control of the associated disease. The viral families in this review are presented with like groups as indicated in Table 1, and not in order of importance.

\subsection{Herpesviridae}

Herpesvirus infections appear to manifest as acute signs which may turn latent and be quiescent for the rest of the animal's life, or until the host becomes sufficiently stressed for the virus to reappear as a disease [31]. Reptilian herpesviruses fall into the family Herpesviridae together with mammalian and avian herpesviruses. Chelonid herpesvirus 5 and 6 in marine turtles are unassigned species in the Subfamily Alphaherpesvirinae and although other reptilian herpesviruses are still unassigned by the International Committee on Taxonomy of Viruses (ICTV), molecular characterisation of available isolates places them within the Subfamily Alphaherpesvirinae in the proposed genus Chelonivirus [32-34]. Originally herpesviruses were classified according to their host, disease signs and morphology as determined by EM, where the current methods are based on sequencing of the viruses followed by phylogenetic analysis. Because many of the viruses described prior to development of these methods have not or cannot be sequenced, there is some confusion as to their taxonomic position. This review will use the classification of chelonian herpesviruses based on sequence analysis as proposed by Bicknese et al. [34] with the ICTV classification in brackets when known. 
Table 1 List of virus families of importance to reptile health with genome and presence of envelope indicated

\begin{tabular}{lll}
\hline Virus family & Genome & Envelope \\
\hline Herpesviridae & Ds DNA & + \\
\hline Iridoviridae & Ds DNA & + \\
\hline Poxviridae & Ds DNA & + \\
\hline Adenoviridae & Ds DNA & - \\
\hline Papillomaviridae & Ds DNA & - \\
\hline Parvoviridae & Ss DNA & - \\
\hline Reoviridae & Ds RNA & - \\
\hline Retroviridae & Pos SS RNA & + \\
\hline Flaviviridae & Pos ss RNA & + \\
\hline Togaviridae & Pos ss RNA & + \\
\hline Caliciviridae & Pos ss RNA & - \\
\hline Picornaviridae & Pos SS RNA & - \\
\hline Paramyxoviridae & Neg SS RNA & + \\
\hline Rhabdoviridae & Neg sS RNA & + \\
\hline
\end{tabular}

Chelonid fibropapilloma-associated herpesvirus (CFPHV) (Chelonid herpesvirus 5), is associated with the development of fibropapillomas and fibromas in marine turtles in all tropical waters, both externally on the epidermis, eyes, carapace and plastron, and in severe cases on the serosal surface of internal organs [35-40]. Fibropapillomatosis (FP) is a major chronic disease of juvenile green turtles and was considered the most significant cause of strandings and mortality in waters around Florida [41] and Hawaii [42]. An infection by fibropapillomatosis herpesvirus appears to be associated with oncogenesis under certain circumstances and considerable research effort has focused on the resultant disease: fibropapillomatosis of marine turtles [8,13,39,41,43-45].

Although many biotic factors such as leeches, mites, other viruses and algal blooms as well as abiotic environmental factors and adjacent land use are associated with FP of wild turtles [32,34,46-49], the CFPHV is implicated as the etiological agent of the disease [20,43,50-52]. It is suspected to operate under certain environmental conditions and in synergy with immune system modulators which may influence the persistence and severity of the lesions $[38,40,44,53,54]$. Wildlife and environmental management agencies are particularly concerned due to the potential population impact this disease could exert on otherwise threatened species [55].

The lung-eye-trachea disease-associated virus (LETV) (Chelonid herpesvirus 6), was first described in 1 year old green turtles raised in mariculture. As the name implies, the virus affects the eyes and respiratory tract of the turtles and has a clinical course of 2-3 weeks. The virus was cultured in green turtle kidney cells and initially visualized by EM [56]. The ability of LETV to grow in vitro has enabled further study of this virus and the development of serological tools to detect previous exposure to the virus in turtles $[57,58]$.

Grey Patch Disease (GPD)-associated virus (Chelonid herpesvirus 1) affecting cultured green turtle hatchlings (Chelonia mydas) was reported to cause mortalities in 5$20 \%$ of the severely afflicted animals [59]. The disease appeared as circular papular skin lesions coalescing into diffuse grey skin lesions with superficial epidermal necrosis and can affect $90-100 \%$ of all hatchlings. The lesions were characterised by hyperkeratosis and hyperplasia with acanthosis. Epidermal cells displayed basophilic intranuclear inclusions and marginated chromatin. Intranuclear enveloped particles of 160-180 nm with an electron dense core of 105-120 nm were visualised by EM. Transmission is thought to be vertical or water-borne [59]. Sudden changes in water temperature could bring about the onset of symptoms in tank reared turtles [60], with low water temperatures leading to a longer lasting but less severe disease than high water temperatures [61].

Two herpesviruses from loggerhead turtles (Caretta caretta) were identified by PCR in lesions of moribund animals [32]. One virus was termed the "loggerhead genital-respiratory herpesvirus" (LGRV), and the other the "loggerhead orocutaneous herpesvirus" (LOCV) according to the lesions they were identified from. Both viruses were thought to be opportunistic in debilitated turtles.

Tortoise Herpesviruses

Herpesviruses are now commonly identified in tortoises of zoological collections due to improved diagnostic methods and several strains have been described and classified into tortoise herpesviruses 1 to 4 (THV1-4) [34,62-64]. Pathological changes caused by herpesvirus infections in tortoises include hepatitis, stomatitis, respiratory tract infection, conjunctivitis and central nervous system involvement [65-70].

Elapid herpesvirus (Indian cobra herpesvirus) was associated with degeneration and focal necrosis of columnar glandular epithelial cells in the venom gland of Siamese cobras (Naja naja kaouthia) with reduced venom production [71].

Herpesviruses have also been detected in lizards: Green lizard herpesvirus was identified in Green lizard papillomas. It was accompanied by two other viruses [72], and may have been an incidental finding of an otherwise latent infection. Herpesviruses were also identified in lizards with stomatitis [73,74] and were named Varanid herpesvirus 1 or gerrhosaurid herpesviruses 1-3. Iguanid herpesvirus 1 was isolated during routine tissue explants from the spleen, kidney and heart of a normal adult Iguana iguana [28].

\subsection{Iridoviridae}

\subsubsection{Ranavirus}

Ranavirus is a genus in the Iridoviridae family represented by the type species Frog Virus 3 (FV3). Previous 
accounts of iridovirus causing systemic infections were later classified as ranavirus in many cases. Ranavirus has received increasing attention due to its involvement in serious diseases of fish and amphibians to the extent that epizootic haematopoietic necrosis virus (EHNV) in fish and ranavirus in general for amphibians meet the criteria for listing by the World Organization for Animal Health (OIE) [75]. Ranaviruses have been implicated in the world-wide decline of amphibians and mass mortalities in both aquaculture and wild fish stock. Some of these isolates are very similar on a serological and molecular level [76-80] and have been reported to be able to infect hosts across classes $[10,81,82]$. This ability of the virus has the potential to compromise prevention and control measures, since amphibians, reptiles and fish may act as reservoir species for each other.

Until recently, overt diseases in reptiles caused by systemic iridovirus were only rarely reported: namely in a spur-tailed Mediterranean land tortoise, Testudo hermanni [83] and a gopher tortoise (Bopherus polyphemus) [84]. However, with increased awareness, several instances of severe mortality events in reptiles associated with ranavirus infections have been described in the last decade in both zoological collections [9,85-87], free-ranging [10], and farmed reptiles [88]. Retrospective studies of archival material may bring even more cases to light. Challenge studies were carried out on red eared sliders (Trachemys scripta elegans) with a ranavirus isolate from Burmese Star tortoise. The red eared sliders developed clinical signs and lesions consistent with those observed in the Burmese tortoises. Virions were observed in lesions by EM and ranavirus was re-isolated from challenged animals [89].

Ranavirus infections of reptiles appear to target multiple organs including the stomach, oesophagus, lungs, spleen, liver and kidney, although some isolates may have a propensity for infecting the respiratory tract $[10,85,87]$. Intracytoplasmic inclusion bodies can be identified in some cases and in addition to virus isolation in established cell lines [27], diagnosis is made on the basis of immuno assays and PCR targeting the major capsid protein or the polymerase gene $[78,87,90]$. Benetka et al., [91] reported co-infection with ranavirus and chelonid herpesvirus in a severely ill leopard tortoise. The diagnosis was made by PCR from pharyngeal and oral swabs, but the tortoise was also compromised by a mixed bacterial infection and recovered after antibiotic treatment, showing that ranavirus may have been a co-infection or a pre-disposing factor rather than the primary cause of the disease. Ranaviruses are easily cultured in vitro and their genome has been studied extensively [78,82,90,92].

\subsubsection{Erythrocytic virus}

Cytoplasmic inclusions in erythrocytes of amphibians, fish and reptiles have long been known to be of iridoviral origin due to light and EM [93-96]. The infection could possibly contribute to anaemia in the host although the clinical significance is not clear. Recently, Wellehan et al. characterised an erythrocytic iridovirus by means of molecular techniques and found that it falls in a group all of its own within the Iridoviridae and may represent a new genus [97].

\subsubsection{Iridovirus}

Although viruses in this genus mostly occur in invertebrates, they do occasionally occur in reptiles [98] and may contribute to disease, but the latter is not clear. Viruses from this genus are, however, often isolated from the prey animals of reptiles, for example commercially grown crickets fed to lizards, and could be incidental residents in the reptile hosts rather than actually infecting and replicating in them [99]. They do grow in reptilian cell lines such as Viper Heart (VH-2) and Terrapene Heart (TH-1) which indicate that they can infect reptiles and isolates from a chameleon (Chamaeloe hoehnelii) were found to be highly pathogenic to crickets (Gryllus bimaculatus) [99] showing that reptiles may be reservoirs for an invertebrate virus.

\subsection{Poxviridae}

Poxviruses have been identified in skin lesions of Caiman sclerops and Caiman crocodilus fuscus [100-102] Crocodylus niloticus, C. porosus and C. johnstoni [103-107]. The lesions presented as brown raised ulcers on the ventral skin, the head region or in the oral cavity. Eosinophilic intracytoplasmic inclusions were observed within hypertrophied epithelial cells. At higher magnification (EM) the inclusions were seen to be viral arrays consisting of pox-like virions $100-200 \mathrm{~nm}$ in diameter, which is small compared to poxviruses of other vertebrates and insects. In all cases, morbidity was high, and mortality low, but due to the disfiguring nature of the disease, it is still an economically important disease for crocodile farming. A single case of poxvirus in the deep epidermal cells of a Hermann tortoise (Testudo hermanni) that succumbed to broncho-pneumonia [108], a co-infection with Chlamydia in a flap-necked chameleon (Chamaeleo dilepsis) [109] and a tegu (Tupinambis teguixin) with poxviral dermatitis that healed spontaneously over four months have also been reported [110], but generally, poxvirus infections of reptiles do not seem to be widespread. Molecular analysis by Afonso et al. [111] places crocodile pox virus from Nile crocodiles in a new proposed genus within the Chordopoxvirinae.

\subsection{Adenoviridae}

Adenoviruses cause respiratory infections in many vertebrate species. Infections have been diagnosed in crocodiles, [112,113], snakes [17,114-116], lizards [17,117-119] and turtles $[120,121]$. Infections in reptiles can be accompanied by lethargy, neurological disorder, esophagitis, hepatitis, splenitis or gastroenteritis $[114,117,118,121]$. 
Adenovirus was isolated in vitro from a lizard [17] and a Corn snake, where the subsequent cytopathic effect (CPE) observed in cell cultures included intranuclear inclusion bodies and finally cell lysis [122]. Diagnosis of adenovirus is now largely done by molecular tools such as PCR directly on swabs or organs followed by sequencing [123] or in situ hybridisation of formalin fixed tissues [124].

A great amount of work has gone into the phylogenetic analysis of adenoviruses, which has resulted in the proposal for creation of three new genera recently in addition to the Mastadenovirus and Aviadenovirus genera which traditionally covered mammalian and avian adenoviruses respectively [125]. The latest addition is Ictadenovirus which hosts a single member from a fish, namely the White sturgeon adenovirus 1. Atadenovirus was named according to the very high $\mathrm{A}+\mathrm{T}$ genome base composition in some of the early viruses in this group, which encompass viruses from reptilian, avian and mammalian hosts. Until recently, all reptile adenoviruses belonged to the Atadenovirus genus indicating strong co-evolution of the host and virus. Siadenoviruses have a very small genome $(30 \mathrm{~kb})$ and a putative sialidase gene at the terminus of the genome, which gave rise to the name of this genus [126]. In 2009, Rivera et al. characterised an adenovirus from Sulawesi tortoises (Indotestudo forsteni) by sequence analysis as a novel adenovirus of the genus Siadenovirus which currently makes it the only reptile virus in this genus [127]. The chelonian adenovirus recently described by Farkas [121] does not fit into any of the recognized genera of the adenovirus family.

\subsection{Papillomaviridae}

Two side-necked turtles (Platemys platycephala) exhibited symptoms of circular papular skin lesions on the head and forelimbs [128]. Histological examination of the epidermis revealed hyperkeratosis and hyperplasia with acanthosis, but no inclusions were observed. Intranuclear crystalline arrays of hexagonal particles of $42 \mathrm{~nm}$ diameter were visualised by electron microscopy. The particles resembled papilloma virions similar to those seen in mammalian wart lesions [128]. Drury et al. identified papilloma-like particles in lung-washings of a Horsfield Russian tortoise [62].

Papilloma-associated viruses were also identified via EM of benign papillomas from Green lizards (Lacerta viridis) by Raynaud and Adrian [72]. The virions were found only in the highly keratinised regions of the papillomas and displayed morphologies similar to papillomavirus, herpesvirus and reovirus. These mixed viral infections were consistent in the three animals examined. None of the viruses were cultivated in vitro [72]. Although the etiological agent of the papillomas could not be determined with confidence, the papillomavirus was implicated because this group is often associated with papillomas in mammals [129]. The other two viruses may have been incidental findings.

Lately, papillomavirus was reported in samples from sea turtles, green turtle (Chelonia mydas) and loggerhead turtle (Caretta caretta) with fibropapillomatosis [32,130]. Herbst et al. [49] characterised the two papillomaviruses and found that they fall into a distinct chelonian clade.

\subsection{Parvoviridae}

The only parvovirus recorded in reptiles is the Dependovirus which requires the presence of an adenovirus infection for replication. This virus was found associated with an adenovirus in intestinal epithelium of several snake species [114,131-133] and in the intestinal tract and liver of a bearded dragon, Pogona vitticeps $[119,134]$. The virus was isolated from a royal python and identified as serpentine adeno-associated virus by Farkas et al. [133].

\subsection{Reoviridae}

Reoviruses can cause severe and often fatal disease in reptiles typically presenting as pneumonia and neurological disorder [135-137]. Reovirus were isolated from the kidney, liver and spleen of a moribund python (Python regius) and from the brain of a rattlesnake exhibiting neurological symptoms $[26,136]$. The isolates grew in iguana (IgH2) and Vero cells respectively and displayed a CPE of syncytical giant cell formation [136] typical of reptilian reovirus [138]. Lamirande et al. isolated reovirus from two dead elaphid snakes and were able to induce pneumonia and tracheitis in a black ratsnake (Elaphe obsolete), re-isolate the virus and induce similar symptoms in another black ratsnake [137]. A reovirus was also one of three viruses associated with papillomas in the Green lizard Lacerta viridis [72]. Reoviruses are fusogenic and grow readily in cell culture [138]. Identification is by PCR and subsequent genomic analysis of reptilian isolates has so far placed them all in the Orthoreovirus genus [135].

\subsection{Retroviridae and inclusion body disease of Boid snakes}

Retroviruses often appear as incidental findings with no disease reported in turtles, crocodiles, tuataras, a Komodo dragon and snakes [19,139-142]. They have been associated with tumours in snakes though $[143,144]$. One of the most commonly reported disease in captive snakes is the inclusion body disease of Boid snakes and although the etiology of the disease is unknown [145], a retroviral infection is often associated [146-149]. The disease is characterised by intracytoplasmic inclusions consisting of a distinctive protein and affected snakes exhibit neurological disorders and regurgitation of food in some species, associated with stomatitis, pneumonia and tumours [150]. The disease may be subclinical, protracted for months or 
terminal within a few weeks of first clinical signs. Eosinophilic intracytoplasmic inclusion bodies can be present in epithelial cells of all major organs, and meningo-encephalitis is prominent. Supernatant from primary cell cultures of the kidney from an infected boa constrictor (Boa constrictor) was inoculated into young Burmese pythons (Python molurus bivittatus) with a resultant IBD development [151]. This disease is often found in snakes from collections with severe mite infestations [145].

With the advance of molecular techniques, endogenous retroviruses are identified in many vertebrates, including reptiles [146]. Huder et al. found highly expressed retroviral activity in all individuals of Python curtus but not in other boid species, irrespective of them displaying the symptoms of inclusion body disease which further clouds the etiological origins of this disease [146].

\subsection{Arboviruses}

Arboviruses are arthropod borne viruses that multiply in both the arthropod vector and the vertebrate host [152]. Many are pathogenic to humans, but reptiles and amphibians can represent an alternative host in which the virus may overwinter in hibernating reptiles and in some cases produce overt disease [153]. Some flaviviruses, togaviruses, rhabdoviruses and a bunyavirus found in reptiles have been classified as arboviruses.

Chaco, Timbo and Marco rhabdoviruses were isolated from the lizard Ameiva ameiva and classified by EM [154]. They grew well in mammalian cell lines with an optimal temperature of $30^{\circ} \mathrm{C}$ and showed no serological cross-reactivity with other rhabdoviruses [155]. Despite their classification as arboviruses, it still remains unclear if Chaco, Timbo and Marco viruses are able to create sufficient viremia to serve as a source for arthropod infection and the infection was not associated with disease in the reptilian host [156]. Likewise, a virus identified as Bunyamwera was isolated from a turtle (Trionyx spinifer emoryi) during a survey of reptiles in Texas in 1970 and 71 [157]. There is no report on the health of the turtle, but the case confirms the role of reptiles as reservoirs for viruses that cause severe disease in humans.

\subsubsection{Flaviviridae}

Antibodies to St Louis encephalitis virus and Japanese encephalitis virus (JEV) have been reported from turtles and snakes [158-160]. Lee et al. [22] isolated JEV from a Chinese rat snake (Elaphe rufodorsata) and in 2001, Drury et al. isolated a flavivirus-like agent from a tortoise [25]. Much of the early evidence for flavivirus infection in reptiles is associated with investigations into their role as reservoirs for this zoonosis, but rarely was the infection reported with disease. When a new strain of West Nile Fever crossed the Atlantic in 1999 and continued across the United States from east to west, much effort went into finding alternative hosts and reservoirs for the virus, focussing the attention back to reptiles among other animals.

Sero-surveys detected antibodies to West Nile Fever virus (WNV) in farmed Nile crocodiles in Israel, farmed crocodiles in Mexico, wild alligators in Florida and freerange American alligators in Louisiana [5,6,153,161]. The virus was found to be associated with disease and mortality in farmed alligators in Georgia, Louisiana and Florida $[153,162,163]$. Alligators with symptoms in Florida were investigated and a very high load of WNV was detected in the livers with pathological changes in multiple organs [153]. A subsequent transmission study proved the pathogenicity of the isolate to inoculated and cohabiting alligators [7].

\subsubsection{Togaviridae}

This group of viruses includes members such as Eastern equine encephalitis virus (EEEV), Western equine encephalitis virus (WEEV) and Venezuelan equine encephalitis [152]. Although infection by these viruses appears to be common according to antibody surveys, which detected antibodies against the viruses in several snake, lizard, turtle and one crocodilian species [157,164], there is little evidence of them causing disease in the reptile hosts. Rather, reptiles may function as reservoir hosts due to their low metabolic rate and subsequent reduced immune response in winter [164].

Experimental infection of snakes and tortoises show them to be highly susceptible [1] with viraemia lasting from 3 to 105 days post infection depending on temperature [2]. Hayes et al. found that neutralising antibody persisted for at least 44 days after the viraemia had subsided [1]. Higher ambient temperatures during the experimental trials appeared to raise the titre of antibodies against the virus and reduce the duration of an infection [2].

Isolation of togaviruses from reptiles has been attempted predominantly from blood samples with variable results $[152,165]$. This may be due to the cyclical nature of viremias [166]. Rosenbusch was able to isolate WEEV from the brain of Bothrops alternata, but not from the blood, showing that blood may not be the best organ for viral isolation, and that the virus may replicate in other organs during periods of low or no viremia [21].

One incidence of feeding by an WEEV-infected mosquito (Culex tarsalis) was sufficient to transmit the infection to a garter snake [167]. Viremia lasted 70 days post hibernation in snakes that were bitten by infected mosquitoes before hibernation [168]. Conversely, 31\% of mosquitoes became infected after feeding on snakes with low level viremia. Vertical transmission between infected mothers and offspring has also been documented for WEEV in garter snakes [165]. A three years survey of blood meals from mosquitoes in an EEEV endemic area in Alabama $[169,147]$ revealed that $75 \%$ were from reptiles. 
This is another example of how a human pathogen can be transmitted to, harboured in, and recovered from reptiles with the aid of an arthropod vector.

\subsection{Caliciviridae}

Sixteen isolates of calicivirus were obtained from four species of poikilothermic animals in a zoological collection [23]. Eight Aruba Island rattlesnakes (Crotalus unicolor) were asymptomatic and isolation was obtained by rectal swab. The other eight isolates were obtained at necropsy of animals found dead in their cages. These included four Aruba Island rattlesnakes, two Bell horned frogs (Ceratophrys orata), one rock rattlesnake (C. lepidus) and one eyelash viper (Bothrops schlegeli). Histopathology revealed a variety of inconsistent lesions in the necropsied animals. The isolates grew in Vero cells at $37^{\circ} \mathrm{C}$ and were identified by physicochemical characteristics as belonging to the Caliciviridae. The 16 isolates were antigenically indistinguishable and the strain was designated as reptilian calicivirus Crotalus type 1. These isolates were compared to isolates from feral pinnipeds (San Miguel sea lion calicivirus) and were found to be closely related at the serological and genomic level [170,171], further adding to speculations into how this virus is transmitted between terrestrial reptiles and marine mammals [172].

\subsection{Picornaviridae}

The only record of picornavirus in reptiles is by Helbstad and Bestetti [114]. A boa constrictor with signs of gastrointestinal disease and central nervous system disorder, displayed groups of necrotic cells with intranuclear inclusion bodies throughout the intestinal tract, the liver, pancreas and spleen. Perivascular cuffing was observed in the meninges together with leukoencephalopathy. Adenovirus virions were visualised by EM in the duodenum and spleen, as were picornavirus virions. The latter were small, 22-27 nm diameter, spheroidal and arranged in rows or lattice formation in the cytoplasm of necrotic cells [114]. An Aesculapian snake showed loss of appetite, abnormal faeces and regurgitation. Upon EM examination four different types of viruses were identified in its duodenum, one of which was a picornavirus [114]. In these mixed infections it is difficult to attribute certain pathological changes to a specific virus, and the picornavirus may merely have been an incidental finding of a non-virulent virus. It should however, be noted that other picornaviruses, the human and porcine enteroviruses, manifest first in the alimentary canal, then proceed to the brain, where they can cause encephalitis with subsequent neurological disorders [173].

\subsection{Paramyxoviridae}

Several epizootics in snake collections have been attributed to a paramyxovirus infection. The first record was from Switzerland, with a respiratory disease of farmed Fer-de-lance snakes (Bothrops atrox) causing up to $87 \%$ mortality in individual rooms [174]. Subsequent outbreaks were reported in rock rattlesnakes (Crotalus lepidus) and several viper species [30] as well as non-viper species [175-178]. Paramyxovirus has also been reported from the respiratory tract of lizards with pneumonia $[179,180]$. Antibody surveys of captive and wild-caught lizards show that they often have elevated antibody titres against paramyxovirus [181-185].

Terminally ill snakes can display neural symptoms $[30,186]$. However, the target organ seems to be the respiratory tract. Post mortem examination often reveals fluid filled lungs and body cavity [175,187]. Lesions are observed in the lungs and occasionally in the brain. An immuno-histochemical survey of sections from suspected ophidian paramyxovirus infection confirmed that the lungs are the main target organ for the virus and that there is multifocal cytoplasmic staining of infected cells [175].

Virus was isolated from the lungs and brain of infected snakes by propagation in cobra eggs, viper heart, gecko embryo, rattlesnake fibroma and Vero cell lines $[29,30,188]$. The virus grows better at $28^{\circ} \mathrm{C}$ than at $37^{\circ} \mathrm{C}$, produces syncytia and eventually destroys the cell layer [189].

Electron microscopy of in vitro propagated virus showed the virions to be pleomorphic, spheroidal or filamentous particles budding from plasma membranes or as mature enveloped particles in the cytoplasm $[187,188,190]$. Paramyxovirus have also been isolated from a Hermann tortoise (Testudo hermannii) with pneumonia and identified in faeces of farmed Nile crocodiles [113,191]. However, these virions could potentially have derived from infected chickens fed to the crocodiles, rather than from an active gastrointestinal infection of the crocodiles themselves.

On a genomic level, paramyxoviruses from snakes and lizards are closely related, while the one isolate from the tortoise was in the same cluster but more distant to the other isolates [191]. The same study confirmed that the paramyxoviruses of reptiles are distinct from those isolated from other animals and are genetically sufficiently different from other paramyxoviruses to have their own proposed genus: Ferlavirus within the subfamily Paramyxovirinae with Fer-de-Lance virus as the type species [16,192].

\section{Summary}

A multitude of viruses exists in reptiles, some of which are described above, and no doubt many more will be described in the future. Some, but not all cause disease and most of them are not very well studied in terms of virulence, pathogenicity, phylogeny and fulfilment of Koch's postulate, which requires cultivation and 
challenge trials. For viruses like CFPHV that cannot be cultured in vitro, the association with fibropapillomatosis is very strong, but apparently other cofactors are needed before it becomes pathogenic. Transmission may in some cases be via vectors such as arthropods or leeches, whereas others by direct contact presumably, but most transmission routes are unknown. The risk of transfer of viruses between reptiles and humans is negligible due to the thermoregulatory differences between reptilian and mammalian hosts which would limit the suite of pathogens able to grow in both temperature regimes. However, some zoonotic potential exists when certain reptiles act as reservoirs for arboviruses that are pathogenic to humans such as West Nile fever virus.

Compared to fish, poultry and mammalian viruses that are of high importance in our society for either commercial or humanitarian reasons, very little is known about reptilian viruses. Crocodile, turtle and snake farms only exist on a relatively small scale and reptiles still feature as rare and exotic pets although individual specimens may be quite valuable. Specialised veterinary clinics and research scientists take an interest in reptilian viruses though and future directions for research and diagnostic tools are likely to venture further into sero-surveys. Hopefully these will become commercially available, thereby facilitating testing of reptiles prior to transfer between zoological collections to protect valuable specimens from known diseases. As for all other veterinary fields, the future diagnosis of reptilian viruses lies with molecular tools for identification, taxonomy, phylogeny and epidemiology.

\section{Acknowledgements}

I would like to acknowledge Professor Barry Hill for talking me into writing this review in the first place and Dr Gael Kurath for convincing and encouraging me to finish it.

\section{Competing interests}

The author declares that she has no competing interests.

Received: 25 October 2010 Accepted: 21 September 2011

Published: 21 September 2011

\section{References}

1. Hayes RO, Daniels JB, Maxfield HK, Wheeler RE: Field and labora tory studies on eastern encephalitis in warm-and cold-blooded vertebrates. Am J Trop Med Hyg 1964, 13:595-606.

2. Bowen GS: Prolonged western equine encephalitis viremia in the Texas tortoise. Am J Trop Med Hyg 1977, 26:171-175.

3. Doi R, Oya A, Telford RS: A preliminary report on the infection of the lizard. Jap J Med Sci Biol 1968, 21:205-207.

4. Miller DL, Mauel MJ, Baldwin C, Burtle G, Ingram D, Hines IIME, Frazier KS: West Nile virus in farmed alligators. Emerg Infect Dis 2003, 9:794-799.

5. Steinman A, Banet-Noach C, Tal S, Levi O, Simanov L, Perk S, Malkinson M, Shpigel N: West Nile virus infection in crocodiles. Emerg Infect Dis 2003, 9:887-889.

6. McNew RM, Elsey RM, Rainwater TR, Marsland EJ, Presley E: Survey for west Nile virus infection in free-ranging American alligators in Louisiana. Southeast Nat 2007, 6:737-742.
7. Klenk K, Snow J, Morgan K, Bowen R, Stephens M, Foster F, Gordy P, Beckett S, Komar N, Grubler D, Bunning M: Alligators as West Nile virus amplifiers. Emerg Infect Dis 2004, 10:2150-2155.

8. Quackenbush SL, Casey RN, Murcek RJ, Paul TA, Work TM, Limpus CJ, Chaves A, duToit L, Perez JV, Aguirre AA: Quantitative analysis of herpesvirus sequences from normal tissue and fibropapillomas of marine turtles with real-time PCR. Virology 2001, 287:105-111.

9. Marschang RE, Becher P, Posthaus H, Wild P, Thiel HJ, Müller-Doblies U, Kalet EF, Bacciarini LN: Isolation and characterization of an iridovirus from Hermann's tortoises (Testudo hermanni). Arch Virol 1999, 144:1909-1922.

10. Johnson AJ, Pessier AP, Wellehan JFX, Childress A, Norton TM, Stedman NL Bloom DC, Belzer W, Titus VR, Wagner R, Brooks JW, Spratt J, Jacobson ER: Ranavirus infection of free-ranging and captive box turtles and tortoises in the United States. J Wildl Dis 2008, 44:851-863.

11. Greenblatt RJ, Work TM, Balazs GH, Sutton CA, Casey RN, Casey JW: The Ozobranchus leech is a candidate mechanical vector for the fibropapillomaassociated turtle herpesvirus found latently infecting skin tumors on Hawaiian green turtles (Chelonia mydas). Virology 2004, 321:101-110.

12. Flint M, Limpus CJ, Patterson-Kane JC, Murray P, Mills P: Corneal fibropapillomatosis in green sea turtles (Chelonia mydas) in Australia. J Comp Pathol 2010, 142:341-346.

13. Greenblatt RJ, Quackenbush SL, Casey RN, Rovnak J, Balazs GH, Work TM, Casey JW, Sutton CA: Genomic variation of the fibropapilloma-associated marine turtle herpesvirus across seven geographic areas and three host species. J Virol 2005, 79:1125-1132.

14. Jacobson ER, Origgi F: Use of serology in reptile medicine. Semin Avian Exotic Pet Med 2002, 11:33-45

15. Johnson AJ, Wendland L, Norton TM, Belzer B, Jacobson ER: Development and use of an indirect enzyme-linked immunosorbent assay for detection of iridovirus exposure in gopher tortoises (Gopherus polyphemus) and eastern box turtles (Terrapene carolina carolina). Vet Microbiol 2010, 142:160-167.

16. Franke J, Essbauer S, Ahne W, Blahak S: Identification and molecular characterization of 18 paramyxoviruses isolated from snakes. Virus Res 2001, 80:67-74

17. Papp T, Fledelius B, Schmidt V, Kaján GL, Marschang RE: PCR-sequence characterization of new adenoviruses found in reptiles and the first successful isolation of a lizard adenovirus. Vet Microbiol 2009, 134:233-240.

18. Marschang RE, Gleiser CB, Papp T, Pfitzner AJP, Bohm R, Roth BN: Comparison of 11 herpesvirus isolates from tortoises using partial sequences from three conserved genes. Vet Microbiol 2006, 117:258-266.

19. Martin J, Kabat P, Herniou E, Tristem M: Characterization and complete nucleotide sequence of an unusual reptilian retrovirus recovered from the order Crocodylia. J Virol 2002, 76:4651-4654

20. Lu Y, Wang Y, Yu O Aguirre A, Balazs G, Nerurkar V Yanagihara R: Detection of herpesviral sequences in tissues of green turtles with fibropapilloma by polymerase chain reaction. Arch Virol 2000, 145:1885-1893

21. Rosenbusch F: Equine encephalomyelitis in the Argentine and its experimental aspects. Proc Pacific Sci Cong 1939, 6:209-214.

22. Lee $H$, Min B, Lim Y: Isolation and serologic studies of Japanese encephalitis virus from snakes in Korea. J Korean Am Med Assoc 1972, 15:69-74.

23. Smith AW, Anderson MP, Skilling DE, Barlough JE, Ensley PK: First isolation of calicivirus from reptiles and amphibians. Am J Vet Res 1986, 47:1718-1721.

24. Drury SE, Gough RE, Calvert I: Detection and isolation of an iridovirus from chameleons (Chamaeleo quadricornis and Chamaeleo hoehnelli) in the United Kingdom. Vet Rec 2002, 150:451-452.

25. Drury SE, Gough RE, McArthur SD: Detection and isolation of a flaviviruslike agent from a leopard tortoise (Geochelone paradalis) in the United Kingdom. Vet Rec 2001, 148:452.

26. Vieler E, Baumgärtner W, Herbst W, Köhler G: Characterization of a reovirus isolate from a rattle snake, Crotalus viridis, with neurological dysfunction. Arch Virol 1994, 138:341-344.

27. Ariel E, Nicolajsen N, Christophersen MB, Holopainen R, Tapiovaara H, Bang Jensen B: Propagation and isolation of ranaviruses in cell culture. Aquaculture 2009, 294:159-164.

28. Clark HF, Karzon DT: Iguana virus, a herpes-like virus isolated from cultured cells of a lizard, Iguana iguana. Infect Immun 1972, 5:559-569. 
29. Clark HF, Lief FS, Lunger PD, Waters D, Leloup P, Foelsch DW, Wyler RW Fer de Lance virus (FDLV): a probable paramyxovirus isolated from a reptile. J Gen Virol 1979, 44:405-418.

30. Jacobson ER, Gaskin JM, Simpson CF, Terrell TG: Paramyxo-like infection in a rock rattlesnake. J Am Vet Med Assoc 1980, 177:796-799.

31. Hoff GL, Hoff DM: Herpesviruses of reptiles. In Diseases of Amphibians and Reptiles. Edited by: Hoff GL, Frye FL, und ER Jacobson. Plenum Press, New York, USA; 1984:159-167.

32. Stacy BA, Wellehan JFX, Foley AM, Coberley SS, Herbst LH, Manire CA, Garner MM, Brookins MD, Childress AL, Jacobson ER: Two herpesviruses associated with disease in wild Atlantic loggerhead sea turtles (Caretta caretta). Vet Microbiol 2008, 126:63-73.

33. Davison AJ, Eberle R, Ehlers B, Hayward GS, McGeoch DJ, Minson AC, Pellett PE, Roizman B, Studdert MJ, Thiry E: The order Herpesvirales. Arch Virol 2009, 154:171-177.

34. Bicknese EJ, Childress AL, Wellehan JFX Jr: A novel herpesvirus of the proposed genus Chelonivirus from an asymptomatic bowsprit tortoise (Chersina angulata). J Zoo Wildl Med 2010, 41:353-358.

35. Aguirre AA, Limpus CJ, Spraker TR, Balazs GH: Survey of fibropapillomatosis and other potential diseases of marine turtles from Moreton Bay. Proceedings of the Nineteenth Annual Symposium on Sea Turtle Conservation and Biology 1999, 36.

36. D'Amato AF, Moraes-Neto M: First documentation of fibropapillomas verified by histopathology in Eretmochelys imbricata. Mar Turtle News/ 2000, 89:12-13

37. Harshbarger J: Sea turtle fibropapilloma cases in the registry of tumors in lower animals. Dep Commer NOAA Tech Memo 1991, 63-70.

38. Herbst LH: Fibropapillomatosis of marine turtles. Annu Rev Fish Dis 1994, 4:389-425.

39. Huerta P, Pineda $H$, Aguirre A, Spraker T, Sarti L, Barragán A: First confirmed case of fibropapilloma in a leatherback turtle (Dermochelys coriacea). Dep Commer, NOAA Tech Memo 2000, 193

40. Jacobson E, Buergelt C, Williams B, Harris RK: Herpesvirus in cutaneous fibropapillomas of the green turtle Chelonia mydas. Dis Aquat Organ 1991, 12:1-6.

41. Foley A, Schroeder B, Redlow A, Fick-Child K, Teas W: Fibropapillomatosis in stranded green turtles (Chelonia mydas) from the Eastern United States (1980-1998): trends and associations with environmental factors. J Wildl Dis 2005, 41:29-41.

42. Chaloupka M, Work TM, Balazs GH, Murakawa SKK, Morris R: Cause-specific temporal and spatial trends in green sea turtle strandings in the Hawaiian Archipelago (1982-2003). Mar Biol 2008, 154:887-898.

43. Lu YA, Wang Y, Aguirre AA, Zhao ZS, Liu CY, Nerurkar VR, Yanagihara R: RTPCR detection of the expression of the polymerase gene of a novel reptilian herpesvirus in tumor tissues of green turtles with fibropapilloma. Arch Virol 2003, 148:1155-1163.

44. Work TM, Rameyer RA, Balazs GH, Cray C, Chang SP: Immune status of free-ranging green turtles with fibropapillomatosis from Hawaii. J Wildl Dis 2001, 37:574-581.

45. Yu Q, Lu Y, Nerurkar VR, Yanagihara R: Amplification and analysis of DNA flanking known sequences of a novel herpesvirus from green turtles with fibropapilloma. Arch Virol 2000, 145:2669-2676.

46. Aguirre AA, Balazs GH, Zimmerman B, Spraker TR: Evaluation of Hawaiian green turtles (Chelonia mydas) for potential pathogens associated with fibropapillomas. J Wildl Dis 1994, 30:8-15.

47. Landsberg JH, Balazs GH, Steidinger KA, Baden DG, Work TM, Russell DJ: The potential role of natural tumor promoters in marine turtle fibropapillomatosis. J Aquat Anim Health 1999, 11:199-210.

48. Van Houtan KS, Hargrove SK, Balazs GH: Land use, macroalgae, and a tumor-forming disease in marine turtles. PLoS One 2010, 5:e12900.

49. Herbst LH, Lenz J, Van Doorslaer K, Chen Z, Stacy BA, Wellehan JFX Jr, Manire CA, Burk RD: Genomic characterization of two novel reptilian papillomaviruses, Chelonia mydas papillomavirus 1 and Caretta caretta papillomavirus 1. Virology 2009, 383:131-135.

50. Herbst LH, Sundberg JP, Shultz LD, Gray BA, Klein PA: Tumorigenicity of green turtle fibropapilloma-derived fibroblast lines in immunodeficient mice. Lab Anim Sci 1998, 48:162-167.

51. Quackenbush SL, Work TM, Balazs GH, Casey RN, Rovnak J, Chaves A, duToit L, Baines JD, Parrish CR, Bowser PR: Three closely related herpesviruses are associated with fibropapillomatosis in marine turtles. Virology 1998, 246:392-399.
52. Lackovich J, Brown D, Homer B, Garber R: Association of herpesvirus with fibropapillomatosis of the green turtle Chelonia mydas and the loggerhead turtle Caretta caretta in Florida. Dis Aquat Organ 1999 37:89-97.

53. Aguirre AA, Balazs GH, Spraker TR, Gross TS: Adrenal and hematological responses to stress in juvenile green turtles (Chelonia mydas) with and without fibropapillomas. Physiol Zool 1995, 68:831-854.

54. Work TM, Balazs GH: Relating tumor score to hematology in green turtles with fibropapillomatosis in Hawaii. J Wildl Dis 1999, 35:804-807.

55. Hamann M, Godfrey M, Seminoff J, Arthur K, Barata P, Bjorndal K, Bolten A, Broderick A, Campbell L, Carreras C: Global research priorities for sea turtles: informing management and conservation in the 21st century. Endang Species Res 2010, 11:245-269.

56. Jacobson ER, Gaskin JM, Roelke M, Greiner EC, Allen J: Conjunctivitis, tracheitis, and pneumonia associated with herpesvirus infection in green sea turtles. J Am Vet Med Assoc 1986, 189:1020-1023.

57. Curry SS, Brown DR, Gaskin JM, Jacobson ER, Ehrhart LM, Blahak S, Herbst LH, Klein PA: Persistent infectivity of a disease-associated herpesvirus in green turtles after exposure to seawater. J Wildl Dis 2000, 36:792-797.

58. Coberley SS, Condit RC, Herbst LH, Klein PA: Identification and expression of immunogenic proteins of a disease-associated marine turtle herpesvirus. J Virol 2002, 76:10553-10558.

59. Rebell $H$, Rywlin A, Haines $H$ : A herpesvirus-type agent associated with skin lesions of green sea turtles in aquaculture. Am J Vet Res 1975, 39:1221-1224.

60. Haines $H G$, Rywlin A, Rebell G: A herpesvirus disease of farmed green turtles (Chelonia mydas). Proceedings of World Mariculture Wiley Online Library; 1974, 183-195.

61. Haines $H$, Kleese WC: Effect of water temperature on a herpesvirus infection of sea turtles. Infect Immun 1977, 15:756-759.

62. Drury SE, Gough RE, McArthur S, Jessop M: Detection of herpesvirus-like and papillomavirus-like particles associated with diseases of tortoises. Vet Rec 1998, 143:639.

63. Johnson AJ, Pessier AP, Wellehan JF, Brown R, Jacobson ER: Identification of a novel herpesvirus from a California desert tortoise (Gopherus agassizii). Vet Microbiol 2005, 111:107-116.

64. Marschang RE, Frost JW, Gravendyck M, Kaleta EF: Comparison of 16 chelonid herpesviruses by virus neutralization tests and restriction endonuclease digestion of viral DNA. J Vet Med B Infect Dis Vet Public Health 2001, 48:393-399.

65. Frye FL, Oshiro LS, Dutra FR, Carney JD: Herpesvirus-like infection in two Pacific pond turtles. J Am Vet Med Assoc 1977, 17:882-884.

66. Cox W, Rapley W, Barker I: Herpesvirus-like infection in a painted turtle (Chrysemys picta). J Wildl Dis 1980, 16:445-449.

67. Jacobson ER, Gaskin JM, Wahlquist H: Herpesvirus-like infection in map turtles. J Am Vet Med Assoc 1982, 181:1322-1324.

68. Origgi F, Romero C, Bloom D, Klein P, Gaskin J, Tucker S, Jacobson E: Experimental transmission of a herpesvirus in Greek tortoises (Testudo graeca). Vet Pathol 2004, 41:50-61.

69. Marschang RE, Gravendyck M, Kaleta EF: Herpesviruses in tortoises: investigations into virus isolation and the treatment of viral stomatitis in Testudo hermanni and T. graeca. Zentralb/ Veterinarmed B 1997, 44:385-394.

70. Muro J, Ramis A, Pastor J, Velarde R, Tarres J, Lavin S: Chronic rhinitis associated with herpesviral infection in captive spur-thighed tortoises from Spain. J Wildl Dis 1998, 34:487-495.

71. Simpson CF, Jacobson ER, Gaskin JM: Herpesvirus-like infection of the venom gland of Siamese cobras. J Am Vet Med Assoc 1979, 175:941-943.

72. Raynaud MM, Adrian M: Lésions cutanées à structure papillomateuse associées à des virus chez le lézard vert (Lacerta viridis Laur). C $R$ Acad Sci 1976, 283:845-847, (in French)

73. Wellehan JFX, Johnson AJ, Latimer KS, Whiteside DP, Crawshaw GJ, Detrisac CJ, Terrell SP, Heard DJ, Childress A, Jacobson ER: Varanid herpesvirus 1: a novel herpesvirus associated with proliferative stomatitis in green tree monitors (Varanus prasinus). Vet Microbiol 2005, 105:83-92.

74. Wellehan JFX, Nichols DK, Li L, Kapur V: Three novel herpesviruses associated with stomatitis in Sudan plated lizards (Gerrhosaurus major) and a black-lined plated lizard (Gerrhosaurus nigrolineatus). J Zoo Wildl Med 2004, 35:50-54. 
75. Anonymous: Aquatic Animal Health Code. Office International des Epizooties, 112008.

76. Hedrick RP, McDowell TS, Ahne W, Torhy C, de Kinkelin P: Properties of three iridovirus-like agents associated with systemic infections of fish. Dis Aquat Organ 1992, 13:203-209.

77. Mao J, Hedrick R, Chinchar V: Molecular characterization, sequence analysis, and taxonomic position of newly isolated fish iridoviruses* 1 . Virology 1997, 229:212-220.

78. Hyatt AD, Gould AR, Zupanovic Z, Cunningham AA, Hengstberger S, Whittington RJ, Kattenbelt J, Coupar BE: Comparative studies of piscine and amphibian iridoviruses. Arch Virol 2000, 145:301-331.

79. Pallister J, Gould A, Harrison D, Hyatt A, Jancovich J, Heine H: Development of real time PCR assays for the detection and differentiation of Australian and European ranaviruses. J Fish Dis 2007, 30:427-438,

80. Ariel $E$, Holopainen R, Olesen NJ, Tapiovaara H: Comparative study of ranavirus isolates from cod (Gadus morhua) and turbot (Psetta maxima) with reference to other ranaviruses. Arch Virol 2010, 155:261-271.

81. Moody N, Owens L: Experimental demonstration of the pathogenicity of a frog virus, Bohle iridovirus, for a fish species, barramundi Lates calcarifer. Dis Aquat Organ 1994, 18:95-102.

82. Mao J, Green DE, Fellers G, Chinchar VG: Molecular characterization of iridoviruses isolated from sympatric amphibians and fish. Virus Res 1999 63:45-52.

83. Heldstab A, Bestetti G: Spontaneous viral hepatitis in a spur-tailed Mediterranean land tortoise (Testudo hermanni). J Zoo Wildl Med 1982, 13:113-120.

84. Westhouse RA, Jacobson ER, Harris RK, Winter KR, Homer BL: Respiratory and pharyngo-esophageal iridovirus infection in a gopher tortoise (Gopherus polyphemus). J Wildl Dis 1996, 32:682-686.

85. De Voe R, Geissler K, Elmore S, Rotstein D, Lewbart G, Guy J: Ranavirusassociated morbidity and mortality in a group of captive eastern box turtles (Terrapene carolina carolina). J Zoo Wildl Med 2004, 35:534-543.

86. Marschang RE, Braun S, Becher P: Isolation of a ranavirus from a gecko (Uroplatus fimbriatus). J Zoo Wildl Med 2005, 36:295-300.

87. Hyatt AD, Williamson M, Coupar BE, Middleton D, Hengstberger SG, Gould AR, Selleck P, Wise TG, Kattenbelt J, Cunningham AA, Lee J: First identification of a ranavirus from green pythons (Chondropython viridis). J Wildl Dis 2002, 38:239-252.

88. Chen ZX, Zheng JC, Jiang YL: A new iridovirus from soft-shelled turtle. Virus Res 1999, 63:147-151.

89. Johnson AJ, Pessier AP, Jacobson ER: Experimental transmission of a Ranavirus in western ornate box turtles (Terrapene ornata ornata) and red-eared sliders (Trachemys scripta elegans). Vet Pathol 2007, 44:285-297.

90. Holopainen R, Ohlemeyer S, Schütze H, Bergmann SM, Tapiovaara H: Ranavirus phylogeny and differentiation based on major capsid protein, DNA polymerase and neurofilament triplet $\mathrm{H} 1$-like protein genes. Dis Aquat Organ 2009, 85:81-91.

91. Benetka V, Grabensteiner E, Gumpenberger M, Neubauer C, Hirschmüller B, Möstl K: First report of an iridovirus (Genus Ranavirus) infection in a Leopard tortoise (Geochelone pardalis pardalis). Wien Tierarztl Monatsschr 2007, 94:243-248.

92. Jancovich JK, Mao J, Chinchar VG, Wyatt C, Case ST, Kumar S, Valente G, Subramanian S, Davidson EW, Collins JP: Genomic sequence of a ranavirus (family Iridoviridae) associated with salamander mortalities in North America. Virology 2003, 316:90-103.

93. Telford RS, Jacobsen ER: Lizard erythrocytic virus in east africans cameleons. J Wildl Dis 1993, 29:57-63.

94. Johnsrude JD, Raskin RE, Hoge AY, Erdos GW: Intraerythrocytic inclusions associated with iridoviral infection in a fer de lance (Bothrops moojeni) snake. Vet Pathol 1997, 34:235-238.

95. Stebhens $W$, Johnston M: The viral nature of Pirhemocyton tarentolae. J Ultrastruct Res 1966, 15:543-554.

96. Reno PW, Philippon-Fried M, Nicholson BL, Sherburne SW: Ultrastructural studies of piscine erythrocytic necrosis (PEN) in Atlantic herring (Clupea harengus harengus). J Fish Res Bd Can 1978, 35:148-154.

97. Wellehan JFX, Strik IN, Stacy BA, Childress A, Jacobsen ER, Telford RS: Characterization of an erythrocytic virus in the family iridoviridae from a peninsula ribbon snake (thamnophis sauritus sackenii). Vet Microbiol 2008, 131:115-122.
98. Just F, Essbauer S, Ahne W, Blahak S: Occurence of an invertebrate iridescent-like virus (iridoviridae) in reptiles. J Vet Med B Infect Dis Vet Public Health 2001, 48:685-694.

99. Weinmann N, Papp T, Pedro Alves de Matos A, Teifke JP, Marschang RE: Experimental infection of crickets (Gryllus bimaculatus) with an invertebrate iridovirus isolated from a high-casqued chameleon (Chamaeleo hoehnelii). J Vet Diagn Invest 2007, 19:674-679.

100. Jacobson ER, Popp JA, Shields RP, Gaskin JM: Poxlike skin lesions in captive caimans. J Am Vet Med Assoc 1979, 175:937-940.

101. Penrith ML, Nesbit JW, Huchzermeyer FW: Poxvirus infection in captive juvenile caimans (Caiman crocodilus fuscus) in South Africa. I S Afr Vet Assoc 1991, 62:137-139.

102. Villafane F, Roderiguez G, Martinelli G, Mantilla O: Principales enfermedades que afectan a algunas explotaciones commerciales de Caiman crocodiles fuscus en la coasta norte Colombiana. IUCN, World Conserv 1996, 342-346.

103. Foggin CM: Diseases and disease control on crocodile farms in Zimbabwe. Chipping Norton 1987, 351-362.

104. Horner RF: Poxvirus in farmed Nile crocodiles. Vet Rec 1988, 122:459-462.

105. Pandey GS, Inoue N, Ohshima K, Okada K, Chihaya Y, Fujimoto Y: Poxvirus infection in Nile crocodiles (Crocodylus niloticus). Res Vet Sci 1990, 49:171-176.

106. Huchzermeyer F, Huchzermeyer K, Putterill J: Observations on a field outbreak of pox virus infection in young Nile crocodiles (Crocodylus niloticus). J S Afr Vet Assoc 1991, 62:27-29.

107. Buenviaje GN, Ladds PW, Melville L: Poxvirus infection in two crocodiles. Aust Vet J 1992, 69:15-16

108. Oros J, Rodriguez J, Deniz S, Fernandez L, Fernandez A: Cutaneous poxvirus-like infection in a captive Hermann's tortoise (Testudo hermanni). Vet Rec 1998, 143:508-509.

109. Jacobson ER, Telford RS: Chlamydial and poxvirus infections of circulating monocytes of a flap-necked chameleon (chamaeleo dilepis). J Wildl Dis 1990, 26:572-577.

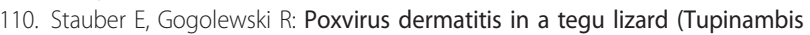
teguixin). J Zoo Wild Med 1990, 21:228-230.

111. Afonso CL, Tulman ER, Delhon G, Lu Z, Viljoen GJ, Wallace DB, Kutish GF, Rock DL: Genome of crocodilepox virus. J Virol 2006, 80:4978-4991.

112. Jacobson $E R$, Gardiner $C H$, Foggin CM: Adenovirus-like infection in two Nile crocodiles. J Am Vet Med Assoc 1984, 185:1421-1422.

113. Huchzermeyer FW, Gerdes GH, Putterill JF: Viruses and mycoplasms from faeces of farmed Nile crocodiles. Proceedings of the 12th working meeting of the Crocodile Specialist Group, IUCN - The World Conservation Union, Gland, Switzerland 1994 1994, 2:303-308.

114. Helbstad A, Bestetti G: Virus associated gastrointestinal diseases in snakes. J Zoo Anim Med 1984, 15:118-128.

115. Jacobson ER, Gaskin JM: Adenovirus-like infection in a boa constrictor. J Am Vet Med Assoc 1985, 185:1226-1227.

116. Schumacher J, Jacobson ER, Burns R, Tramontin RR: Adenovirus-like infection in two rosy boas (Lichanura trivirgata). J Zoo Wildl Med 1994, 25:461-465

117. Jacobson ER, Gardiner CH: Adeno-like virus in esophageal and tracheal mucosa of a Jackson's chameleon (Chamaeleo jacksoni). Vet Pathol 1990, 27:210-212.

118. Frye FL, Munn RJ, Gardner M, Barten SL, Hadfy LB: Adenovirus-like hepatitis in a group of related Rankin's dragon lizards (Pogona henrylawsoni). J Zoo Wildl Med 1994, 25:167-171.

119. Jacobson ER, Kopit W, Kennedy FA, Funk RS: Coinfection of a bearded dragon, Pogona vitticeps, with adenovirus-and dependovirus-like viruses. Vet Pathol 1996, 33:343-346.

120. McArthur S, Wilkinson R, Meyer J: Medicine and Surgery of Tortoises and Turtles 2004.

121. Farkas SL, Gál J: Adenovirus and mycoplasma infection in an ornate box turtle (Terrapene ornata ornata) in Hungary. Vet Microbiol 2009, 138:169-173.

122. Ahne $W$, Juhasz $A$ : In vitro replication of a reptilian adenovirus. Vet Res 1995, 26:443-448.

123. Wellehan JFX, Johnson AJ, Harrach B, Benkö M, Pessier AP, Johnson M, Garner M, Childress A, Jacobson ER: Detection and analysis of six lizard 
adenoviruses by consensus primer PCR provides futher evidence of a reptilian origin for the atadenoviruses. J Virol 2004, 78:13366-13369.

124. Perkins LE, Campagnoli RP, Harmon BG, Gregory CR, Steffens W, Latimer K, Clubb S, Crane M: Detection and confirmation of reptilian adenovirus infection by in situ hybridization. J Vet Diagn Invest 2001, 13:365-368.

125. Benkö M, Harrach B, Both GW, Russell WC, Adair BM, Adám E, de Jong JC, Hess M, Johnson M, Kajon A, et al: Virus Taxonomy. VIllth Report of the International Committee on Taxonomy of Viruses. Elsevier, New York 2005, 213-228.

126. Davison AJ, Harrach B: Siadenovirus. In The Springer Index of Viruses. New York: Springer-Verlag 2002, 29-33.

127. Rivera S, Wellehan JFX, McManamon R, Innis CJ, Garner MM, Raphael BL, Gregory CR, Latimer KS, Rodriguez CE, Diaz-Figueroa O: Systemic adenovirus infection in Sulawesi tortoises (Indotestudo forsteni) caused by a novel siadenovirus. J Vet Diagn Invest 2009, 21:415-426.

128. Jacobson ER, Gaskin JM, Clubb S: Papilloma-like virus infection in Bolivian side-necked turtles. J Am Vet Med Assoc 1982, 181:1325-1328.

129. Youngson RM: Collins Dictionary of Medicine. Harper Collins Publishers 1992,662

130. Manire CA, Stacy BA, Kinsel MJ, Daniel HT, Anderson ET, Wellehan JFX Jr: Proliferative dermatitis in a loggerhead turtle, Caretta caretta, and a green turtle, Chelonia mydas, associated with novel papillomaviruses. Vet Microbiol 2008, 130:227-237.

131. Ahne W, Scheinert P: Reptilian viruses: isolation of parvovirus like particles from corn snake Elapha guttata (Colubridae). Zentralbl Veterinarmed B 1989, 36:409-412.

132. Wozniak E, DeNardo D, Brewer A, Wong V, Tarara R: Identification of adenovirus-and dependovirus-like agents in an outbreak of fatal gastroenteritis in captive born California mountain kingsnakes, Lampropeltis zonata multicincta. J Herpetol Med Surg 2000, 10:4-7.

133. Farkas LS: Adenoviruses of reptiles. Magyar Allatorvosok Lapja 2004 126:212-216

134. Kim DY, Mitchell MA, Bauer RW, Poston R, Cho DY: An outbreak of adenoviral infection in inland bearded dragons (Pogona vitticeps) coinfected with dependovirus and coccidial protozoa (Isospora sp.). J Vet Diagn Invest 2002, 14:332-334.

135. Wellehan JFX, Childress AL, Marschang RE, Johnson AJ, Lamirande EW, Roberts JF, Vickers ML Gaskin JM, Jacobson ER: Consensus nested PCR amplification and sequencing of diverse reptilian, avian, and mammalian orthoreoviruses. Vet Microbiol 2009, 133:34-42.

136. Ahne W, Thomsen I, Winton J: Isolation of a reovirus from the snake, Python regius. Arch Virol 1987, 94:135-139.

137. Lamirande EW, Nichols DK, Owens JW, Gaskin JM, Jacobson ER: Isolation and experimental transmission of a reovirus pathogenic in ratsnakes (Elaphe species). Virus Res 1999, 63:135-141.

138. Corcoran JA, Duncan R: Reptilian reovirus utilizes a small type III protein with an external myristylated amino terminus to mediate cell-cell fusion. J Virol 2004, 78:4342-4351.

139. Herniou E, Martin J, Miller K, Cook J, Wilkinson M, Tristem M: Retroviral diversity and distribution in vertebrates. J Virol 1998, 72:5955-5966.

140. Martin J, Herniou E, Cook J, Waugh ON: Human endogenous retrovirus type I-related viruses have an apparently widespread distribution within vertebrates. J Virol 1997, 71:437-443.

141. Tristem M, Myles T, Hill F: A highly divergent retroviral sequence in the tuatara (Sphenodon). Virology 1995, 210:206-211.

142. van Regenmortel MHV, Fauquet C, Bishop DHL, Carstens E, Estes M, Lemon S, Maniloff J, Mayo M, McGeoch D, Pringle C: Virus taxonomy: classification and nomenclature of viruses. Seventh report of the International Committee on Taxonomy of Viruses Academic Press; 2000.

143. Jacobson ER, Seely JC, Novilla MN: Lymphosarcoma associated with viruslike intranuclear inclusions in a California king snake (Colubridae: Lampropeltis). J Natl Cancer Inst 1980, 65:577-583.

144. Ippen R, Mladenov Z, Konstantinov A: Leukosis with viral presence proven by means of an electron microscope in 2 boa constrictors. Schweiz Arch Tierheilkd 1978, 120:357-368, (in German).

145. Chang LW, Jacobson ER: Inclusion body disease, a worldwide infectious disease of boid snakes: a review. J Exotic Pet Med 2010, 19:216-225.

146. Huder JB, Böni J, Hatt JM, Soldati G, Lutz H, Schupbach J: Indentification and characterization of two closely related unclassifiable endogenous retroviruses in pythons (python molurus and python curtus). J Virol 2002, 76:7607-7615.
147. Wozniak E, McBride J, DeNardo D, Tarara R, Wong V, Osburn B: Isolation and characterization of an antigenically distinct 68-kd protein from nonviral intracytoplasmic inclusions in Boa constrictors chronically infected with the inclusion body disease virus (IBDV: Retroviridae). Vet Pathol 2000, 37:449-459.

148. Carlisle Nowak M, Sullivan N, Carrigan M, Knight C, Ryan C, Jacobson E: Inclusion body disease in two captive Australian pythons (Morelia spilota variegata and Morelia spilota spilota). Aust Vet J 1998, 76:98-100.

149. Jacobson ER, Orós J, Tucker SJ, Pollock DP, Kelley KL, Munn RJ, Lock BA, Mergia A, Yamamoto JK: Partial characterization of retroviruses from boid snakes with inclusion body disease. Am J Vet Res 2001, 62:217-224.

150. Jacobson ER: Infectious diseases and pathology of reptiles: color atlas and text 2007, CRC.

151. Schumacher J, Jacobson ER, Homer BL, Gaskin JM: Inclusion body disease in boid snakes. J Zoo Wildl Med 1994, 25:511-524.

152. Shortridge K, Oya A: Arboviruses in reptiles 1984.

153. Jacobson ER, Ginn PE, Troutman JM, Farina L, Stark L, Klenk K, Komar N: West Nile virus infection in farmed American alligators (Alligator mississippiensis) in Florida. J Wildl Dis 2005, 41:96-106

154. Causey OR, Shope RE, Bensabath G: Marco, Timbo and Chaco, newly recognized arboviruses from lizards in Brazil. Am J Trop Med Hyg 1966 15:239-243.

155. Monath TP, Cropp CB, Frazier CL, Murphy FA, Whitfield SG: Viruses isolated from reptiles:identification of three new members of the family Rhabdoviridae. Arch Virol 1979, 60:1-12.

156. Cropp CB: Reptilian Rhabdoviruses. In Diseases of Amphibians and Reptiles. Plenum Press, New York; 1984, 149-157.

157. Hoff G, Trainer DO: Arboviruses in reptiles: isolation of a Bunyamwera group virus from a naturally infected turtle. J Herpetol 1973, 7:55-62.

158. Whitney E, Jamnback H, Means R, Watthews TH: Arthropod-borne virus survey in St. Lawrence County, New York. Arbovirus reactivity in serum from amphibians, reptiles, birds and mammals. Am J Trop Med Hyg 1968, 17:645-650.

159. Shortridge KF, Oya A, Konayashi M, Yip DY: Arbovirus infections in reptiles: Studies on the presence of Japanese encephalitis virus antibody in plasma of the turtle. Southeast Asian J Trop Med Public Health 1975 6:161-169

160. Lee HW: Multiplication and antibody formation of Japanese encephalitis virus in snakes: proliferation of the virus. Seoul J Med 1968, 9:157-161.

161. Farfan-Ale JA, Blitvich BJ, Marlenee NL, Lorono-Pino MA, Puerto-Manzano F, Garcia-Rejon JE, Rosado-Paredes EP, Flores-Flores LF, Ortega-Salazar A, Chavez-Medina J, Cremieux-Grimaldi JC, Correa-Morales F, HernándezGaona G, Méndez-Galván JF, Beaty BJ: Antibodies to West Nile virus in asymptomatic mammals, birds, and reptiles. Am J Trop Med Hyg 2006, 74:908-914.

162. Miller DL, Mauel MJ, Baldwin C, Burtle G, Ingram D, Hines ME: West Nile virus in farmed alligators. Emerg Infect Dis 2003, 9:794-799.

163. Nevarez JG, Mitchell MA, Kim DY, Poston R, Lampinen HM: West Nile virus in alligator, Alligator mississippiensis, ranches from Louisiana. J Herpetol Med Surg 2005, 15:4-9.

164. Lunger PD, Clark HF: Reptilia-related viruses. Adv Virus Res 1978, 23:159-204.

165. Gebhardt LP, Stanton GJ, Hill DW, Collett GC: Natural overwintering hosts of the virus of western equine encephalitis. N Engl J Med 1964, 271:172-177.

166. Burton AN, McLintock J, Rempel J: Western equine encephalitis virus in Saskatchewan garter snakes and leopard frogs. Science 1966, 154:1029-1031

167. Gebhardt LP, Stanton GJ, De St Jeor S: Transmission of WEE virus to snakes by infected Culex tarsalis mosquitoes. Proc Soc Exp Biol Med 1966, 123:233-235.

168. Thomas LA, Eklund CM, Rush WA: Susceptibility of garter snakes (Thamnophis spp.) to western equine encephalomyelitis virus. Proc Soc Exp Biol Med 1958, 99:698-700.

169. Cupp EW, Zhang D, Yue X, Cupp MS, Guyer C, Sprenger TR, Unnasch TR: Identification of reptilian and amphibian blood meals from mosquitoes in an eastern equine encephalomyelitis virus focus in central Alabama. Am J Trop Med Hyg 2004, 71:272-276.

170. Matson DO, Berke T, Dinulos MB, Poet E, Zhong WM, Dai XM, Jiang $X$ Golding B, Smith AW: Partial characterization of the genome of nine animal caliciviruses. Arch Virol 1996, 141:2443-2456. 
171. Barlough JE, Matson DO, Skilling DE, Berke T, Berry ES, Brown RF, Smith AW: Isolation of reptilian calicivirus Crotalus type 1 from feral pinnipeds. $J$ Wildl Dis 1998, 34:451-456.

172. Smith AW, Skilling DE, Cherry N, Mead JH, Matson DO: Calicivirus emergence from ocean reservoirs: zoonotic and interspecies movements. Emerg Infect Dis 1998, 4:13-20.

173. Enterovirus. [http://www.cdc.gov/ncidod/dvrd/revb/enterovirus/nonpolio_entero.htm].

174. von Folsch DW, Leloup P: Fatale endemische infection in einem serpantarium. Tierarztliche Praxis 1976, 4:527-563, (in German).

175. Homer BL, Sundberg JP, Gaskin JM, Schumacher J, Jacobson ER: Immunoperoxidase detection of ophidian paramyxovirus in snake lung using a polyclonal antibody. J Vet Diagn Invest 1995, 7:72-77.

176. Orós J, Sicilia J, Torrent A, Castro P, Arencibia A, Déniz S, Jacobson E, Homer B: Immunohistochemical detection of ophidian paramyxovirus in snakes in the Canary Islands. Vet Rec 2001, 149:21-23.

177. Ahne W, Neubert WJ, Thomsen I: Reptilian viruses: isolation of myxoviruslike particles from the snake Elaphe oxycephala. Zentralbl Veterinarmed $B$ 1987, 34:607-612.

178. Essbauer S, Ahne W: Viruses of lower vertebrates. J Vet Med B Infect Dis Vet Public Health 2001, 48:403-475.

179. Ahne W, Neubert WJ: Isolation of paramyxovirus-like agents from teju (Callopistes maculates) and python (Phyton regius). Oregon State University 1991, 203-210.

180. Jacobson ER, Origgi F, Pessier AP, Lamirande EW, Walker I, Whitaker B, Stalis $I H$, Nordhausen R, Owens JW, Nichols DK: Paramyxovirus infection in caiman lizards (Draecena guianensis). J Vet Diagn Invest 2001, 13:143-151.

181. Marschang RE, Donahoe S, Manvell R, Lemos-Espinal J: Paramyxovirus and reovirus infections in wild-caught Mexican lizards (Xenosaurus and Abronia spp). J Zoo Wildl Med 2002, 33:317-321.

182. Gravendyck M, Ammermann P, Marschang RE, Kaleta EF: Paramyxoviral and reoviral infections of iguanas on Honduran Islands. J Wildl Dis 1998, 34:33-38.

183. Lloyd M: Common infectious diseases of reptiles and amphibians: An etiologic review, diagnostics and treatment recommendations. Proc Assoc Rep Amph Vet 1994, 6-10.

184. Lloyd C, Manvell R, Drury S, Sainsbury A: Seroprevalence and significance of paramyxovirus titres in a zoological collection of lizards. Vet Rec 2005, 156:578-580

185. Allender MC, Mitchell MA, Phillips CA, Gruszynski K, Beasley VR: Hematology, plasma biochemistry, and antibodies to select viruses in wild-caught eastern massasauga rattlesnakes (Sistrurus catenatus catenatus) from Illinois. J Wild Dis 2006, 42:107-114.

186. West G, Garner M, Raymond J, Latimer KS, Nordhausen R: Meningoencephalitis in a Boelen's python (Morelia boeleni) associated with paramyxovirus infection. J Zoo Wildl Med 2001, 32:360-365.

187. Lunger PD, Clark HF: Morphogenesis of Fer-De-Lance virus (FDLV) cultured at optimal (30 C) cell growth temperature. J Comp Pathol 1979, 89:265-279.

188. Richter GA, Homer BL, Moyer SA, Williams DS, Scherba G, Tucker SJ, Hall BJ, Pedersen JC, Jacobson ER: Characterization of paramyxoviruses isolated from three snakes. Virus Res 1996, 43:77-83.

189. Blahak S: Isolation and characterization of paramyxoviruses from snakes and their relationship to avian paramyxoviruses. Zentralbl Veterinarmed $B$ 1995, 42:216-224.

190. Lunger P, Clark H: Morphogenesis of Fer-De-Lance virus (FDLV) cultured at sub-(23 C) and supra-(36 C) optimal cell growth temperature. J Comp Pathol 1979, 89:281-291.

191. Marschang RE, Papp T, Frost J: Comparison of paramyxovirus isolates from snakes, lizards and a tortoise. Virus Res 2009, 144:272-279.

192. Kurath G, Batts WN, Ahne W, Winton JR: Complete genome sequence of Fer-de-Lance virus reveals a novel gene in reptilian paramyxoviruses. J Virol 2004, 78:2045-2056.

doi:10.1186/1297-9716-42-100

Cite this article as: Ariel: Viruses in reptiles. Veterinary Research 2011 42:100.

\section{Submit your next manuscript to BioMed Central and take full advantage of:}

- Convenient online submission

- Thorough peer review

- No space constraints or color figure charges

- Immediate publication on acceptance

- Inclusion in PubMed, CAS, Scopus and Google Scholar

- Research which is freely available for redistribution 